DOI: 10.5604/01.3001.0013.2547

\title{
THE PROSPECTS FOR THE USE OF INTELLIGENT SYSTEMS IN THE PROCESSES OF GRAVITATIONAL ENRICHMENT
}

\author{
Batyrbek Suleimenov, Yelena Kulakova \\ Kazakh National Technical Research University after K.I. Satpayev, Department of Automotion and Control
}

Abstract. Intelligent control systems are actively developing and can significantly reduce financial costs and improve the environmental performance of ore-dressing processes. Usage of intelligent control systems for gravitational enrichment allows to minimize costs and negative influence of ore tails on the environment, exclude losses of concentrate and energy resources in the ore-dressing process. The paper discusses the problems and prospects for the application of intelligent control systems of gravity concentration equipment. A structure of the control system and an intelligent model for determining the frequency of pulsation jigging machine based on fuzzy logic are proposed. The model is based on data obtained from experts, it is researched. The obtained results allow to judge about the prospects for the implementation of intelligent systems in the management of ore enrichment.

Keywords: gravitational enrichment, intelligent system, jigging machine, centrifugal concentrator, fuzzy model

\section{PERSPEKTYWY WYKORZYSTANIA SYSTEMÓW INTELIGENTNYCH W ZARZAQDZANIU PROCESAMI WZBOGACANIA METODĄ GRAWITACYJNA}

Streszczenie. Zastosowanie inteligentnych systemów zarzadzania wzbogacaniem grawitacyjnym zminimalizuje koszty $i$ negatywny wpływ odpadów przeróbczych na środowisko, wyeliminuje straty koncentratu i zasobów energetycznych w procesie zagęszczania rudy. W artykule omówiono problemy $i$ perspektywy zastosowania inteligentnych systemów sterowania urzadzeń do wzbogacania metoda grawitacyjna. Zaproponowano strukture systemu sterowania i model inteligentny do określania częstotliwości maszyny sedymentacyjnej na bazie logiki rozmytej. Model opiera się na danych otrzymanych od ekspertów. Uzyskane wyniki pozwalają nam ocenić perspektywy wdrożenia inteligentnych systemów w procesach kontroli przerobu rudy.

Słowa kluczowe: wzbogacanie grawitacyjne, system inteligentny, maszyna osadowa, koncentrator odśrodkowy, model rozmyty

\section{Introduction}

Modern reality requires the development of not only economical but also environmentally friendly technologies for the production of mineral raw material.

Consequently, there is a need for a thorough processing of ore, especially small and fine classes, which previously fell into the waste of production.

Gravity enrichment methods are known from ancient times and to the end of the XIX century, they were the only methods of mineral processing, because of other methods were practically not used. The concept of gravitational methods is the separation of mineral particles under the action of gravity and resistance forces. Consequently the variety of particles with their individual properties makes it difficult to reliably quantitatively describe gravitational processes. Therefore, the development of this method of enrichment, despite the centuries-old history and wide application, is mainly through experimentation [8].

In the field of gravitational enrichment, in particular, the jigging process, to date, sufficiently effective technologies have been created that allow controlling the process, reducing energy costs for production, and facilitating the work of the operator.

However, existing control systems have several disadvantages, which do not allow to achieve maximum enrichment indicators.

\section{The equipment of gravity enrichment}

The main technological units of gravity enrichment are screens, various separators (screw, magnetic, etc.), concentrators, and also jigging machines. Consider two units for the enrichment of ores of fine and small classes. They are jigging machine and centrifugal concentrator.

Jigging machine - mining machine, equipped with special equipment (sieve, chamber). The jigging process is based on the Rittenger equation:

$$
v_{r}=k_{r} \sqrt{d^{*}(\delta-1)}
$$

where: $v_{r}$ is speed of free fall of particles in water, $\mathrm{k}_{\mathrm{r}}$ is Rittenger coefficient, $\mathrm{d}$ is diameter of particle in $\mathrm{mm}, \delta$ is density of particle in $\mathrm{g} / \mathrm{mm}^{3}$.

Jigging machine is used for gravitational enrichment of ores in the aquatic environment, through the separation of minerals mainly by density. Since the only consumable material is water, the operation of jigging machines is economical and environmentally friendly. These machines work reliably around the world because of their reliability and high performance.

The principle of operation of the centrifugal concentrator consists in the forced separation of the material being processed into two fractions: "heavy" and "light" in the centrifugal field. The separation of material into fractions occurs as a result of the interaction of the flow of wash water, centrifugal forces and the gravitational field acting on the particle in a horizontally or obliquely rotating rotor.

At present, jigging machines and concentrators are widely represented by manufacturers and all, without exception, are equipped with automatic control systems based on modern automation tools [2]. But it is important to note that these systems are automation systems that certainly facilitate the work of a technologist, give average, but not maximum technological indicators of enrichment.

The vulnerability of classical management methods is connected with the multidimensionality of the processes of gravitational enrichment.

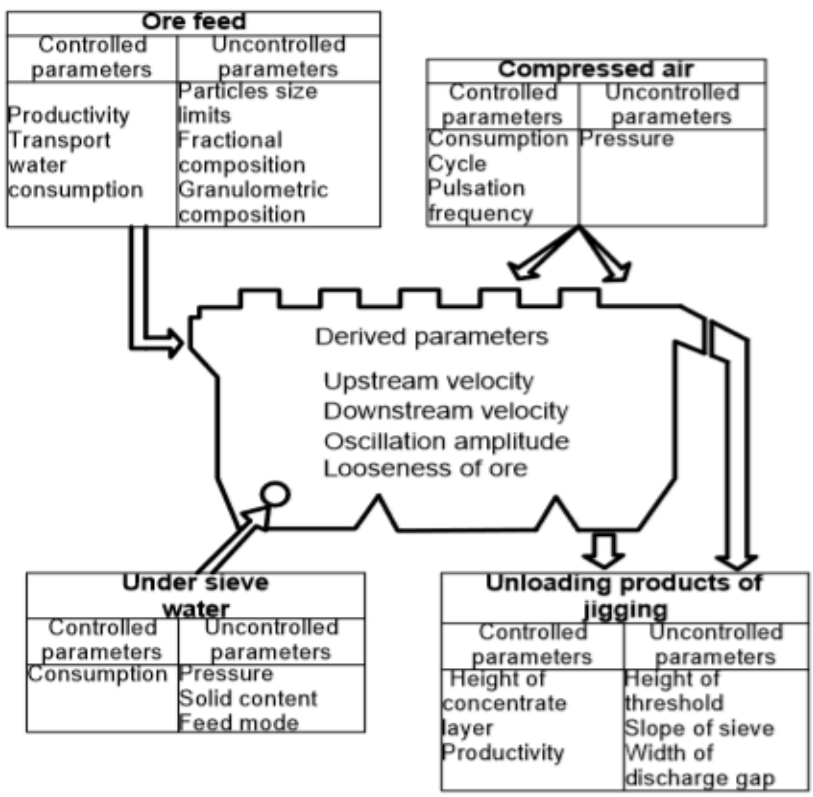

Fig. 1. The parameters of jigging machine 
For example, the technological indicators of the enrichment of jigging machines are simultaneously affected by about 20 factors determined by the characteristics and feed mode of the jigging machines, technological and hydrodynamic parameters of the process (Fig. 1). Many of them are in complex interaction with each other and manifest themselves in different conditions ambiguously.

Consequently, the disadvantage of the existing control systems is that the key variables of gravitational enrichment units are not constantly regulated depending on disturbing factors, they have a fixed value and are changed by the technologist only 2-3 times per shift. A technologist decides on the optimal value of these variables, based on their competence, that is, the human factor is of great importance.

Thus, the analysis of literary sources $[1,4,7]$ and long-term communication with expert technologists, working directly on the equipment of gravity enrichment, suggests that the use of intelligent algorithms in the control systems of the processes of gravitational enrichment will eliminate the shortcomings of the existing automation systems.

\section{Concept of control system for gravitational enrichment processes}

To improve the technological indicators of the enrichment of small classes ore in gravity enrichment equipment to proposed developing a three-level control system (Fig. 2). The proposed system consists of:

- intelligent system generates the optimal value of key variables. To do this the system uses data obtained from field automation units (the composition of the original ore Q, and others) and base of knowledge from the experience of a competent expert technologist;

- controller that maintains the optimal value of the key variables obtained by the intelligent subsystem.

- field automation units (sensor, ore analyzer, actuators, VS converters) directly measure the process variables and produce a physical effect according to the control law adopted by the intelligent system.

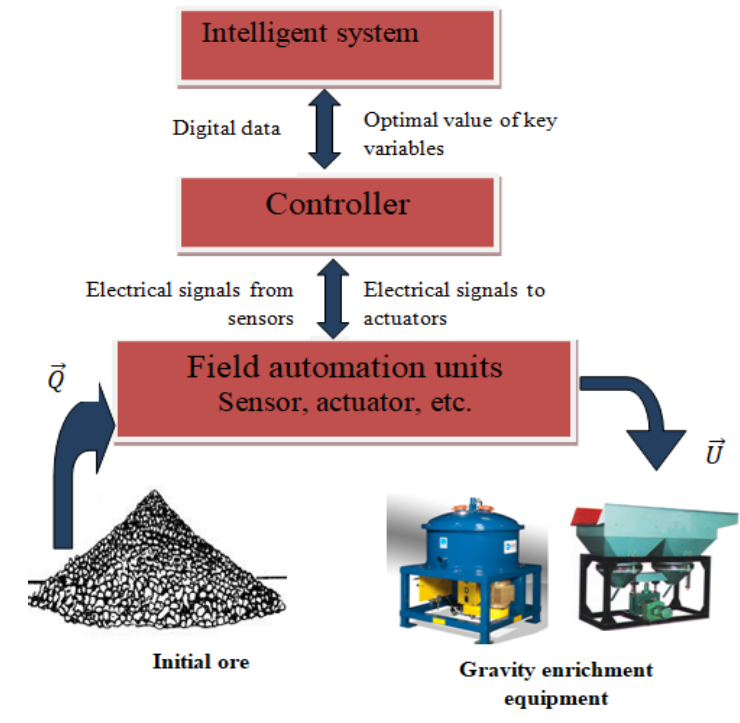

Fig. 2. Concept of control system for gravitational enrichment processes

A distinctive feature of the system being developed is that the value of the key variables of the enrichment process is set not by the operator-technologist, but by the intellectual system. This system is built on the experience of qualified technologists. The adjustment process includes a large number of input variables and, accordingly, all existing control systems leave the right to make decisions for a operator. In this regard, factors such as qualifications, fatigue, inattention of staff, etc., do not allow to achieve the maximum possible technological indicators of enrichment.

Not every technologist has sufficient experience to adjust the parameters of the equipment, and a number of factors depend on the individual characteristics of the worker. That is, the intelligent system allows you to use the experience of the most competent specialist constantly, regardless of the shift and the presence or absence of the person in the workplace. This approach will eliminate the influence of the human factor and improve enrichment rates.

\section{Intelligent model for determining the frequency of pulsation of jigging machine}

The development and research of intelligent models make it possible to assess the effectiveness of the use of intelligent systems for control of the processes of gravitational enrichment. In this regard, the intelligent model for the determining of the key variable of the jigging technology - the pulsation frequency of the jigging part of jigging machine was developed and researched. The modeling was performed in the Matlab environment using the Fuzzy Logic interface.

The developed model allows to determine the optimal values of the pulsation frequency (Y), depending on the initial ore concentration (X1) and chromium concentration in the reject material (X2). The stages of modeling are:

- expert survey, getting the PFE matrix;

- data normalization;

- designation of linguistic variables ;

- definition of the membership function

- selecting a base term-set of a linguistic variable or a set of its values (terms);

- forming the rules of fuzzy products;

- obtaining 2 fuzzy models: one using triangular terms; the second with trapezoid terms;

- testing resulting models.

At the first stage of the synthesis of intelligent models, a planning matrix of a full factorial experiment (PFE) is compiled. Using this matrix, a control model of an object or process is created. In PFE, all possible combinations of levels of factors are implemented. When the number of levels is equal to four for each factor, the PFE matrix consists of $m=4 n$ rows, where $n$ is the number of factors (controlled variables), and $\mathrm{m}$ is the number of experiments [5].

As a result of the questioning of experienced operators, which have been working with jigging machine for a long time the PFE matrix was obtained (table 1).

Table 1. The PFE matrix

\begin{tabular}{|c|c|c|}
\hline \multicolumn{2}{|c|}{ Factors } & Optimal value \\
\hline $\begin{array}{c}\text { Concentration } \\
\text { of initial ore }\end{array}$ & $\begin{array}{c}\text { Chromium } \\
\text { concentration in } \\
\text { reject material }\end{array}$ & $\begin{array}{c}\text { Frequency } \\
\text { of pulsation }\end{array}$ \\
\hline $\mathrm{X} 1$ & $\mathrm{X} 2$ & $\mathrm{Y}$ \\
\hline 28 & 2 & 55 \\
\hline 32 & 2 & 60 \\
\hline 36 & 2 & 69 \\
\hline 40 & 2 & 75 \\
\hline 28 & 8 & 60 \\
\hline 32 & 8 & 69 \\
\hline 36 & 8 & 70 \\
\hline 40 & 8 & 75 \\
\hline 28 & 14 & 63 \\
\hline 32 & 14 & 63 \\
\hline 36 & 14 & 66 \\
\hline 40 & 14 & 72 \\
\hline 28 & 20 & 60 \\
\hline 32 & 20 & 65 \\
\hline 36 & 20 & 70 \\
\hline 40 & 20 & 75 \\
\hline
\end{tabular}


Next, the normalization of input and output variables is carried out in the range from 0 to 1 according to the equation:

$$
\bar{x}=\frac{x-x_{\min }}{x_{\max }-x_{\min }}
$$

where: $x$ is the normalized value of the input or output variable, $\mathrm{x}$ is the current value of the variable, $\mathrm{x}_{\min }, \mathrm{x}_{\max }$ is the minimum and maximum value of the variable.

As a result of data normalization is table 2 .

Table 2. Normalized data

\begin{tabular}{|c|c|c|}
\hline \multicolumn{2}{|c|}{ Factors } & Optimal value \\
\hline $\begin{array}{c}\text { Concentration } \\
\text { of initial ore }\end{array}$ & $\begin{array}{c}\text { Chromium } \\
\text { concentration } \\
\text { in reject material }\end{array}$ & $\begin{array}{c}\text { Frequency } \\
\text { of pulsation }\end{array}$ \\
\hline $\mathrm{X} 1$ & $\mathrm{X} 2$ & $\mathrm{Y}$ \\
\hline 0.00 & 0.00 & 0 \\
\hline 0.33 & 0.00 & 0.25 \\
\hline 0.67 & 0.00 & 0.7 \\
\hline 1.00 & 0.00 & 1 \\
\hline 0.00 & 0.33 & 0.25 \\
\hline 0.33 & 0.33 & 0.7 \\
\hline 0.67 & 0.33 & 0.75 \\
\hline 1.00 & 0.33 & 1 \\
\hline 0.00 & 0.67 & 0.4 \\
\hline 0.33 & 0.67 & 0.4 \\
\hline 0.67 & 0.67 & 0.55 \\
\hline 1.00 & 0.67 & 0.85 \\
\hline 0.00 & 1.00 & 0.25 \\
\hline 0.33 & 1.00 & 0.5 \\
\hline 0.67 & 1.00 & 0.75 \\
\hline 1.00 & 1.00 & 1 \\
\hline
\end{tabular}

In table 2, all variables are given to normalized form in the range from 0.0 to 1.0 . The concentration of chromium in the original (initial) ore $28 \%$ corresponds to 0.0 and $40 \%-1$; chromium concentration in reject material material (tailings) $2 \%$ corresponds to 0.0 and $20 \%-1$, the minimum frequency of pulsation $55 \%-0$, maximum $75 \%-1$.

At the next stage notation for the linguistic variables is introduced: input: the initial concentration of ore (X1) and the concentration of chromium in reject material (tails)(X2); output: pulsation frequency of jigging part of machine (Y).

When solving practical problems of fuzzy modeling, the simplest fuzzy numbers and intervals - triangular and trapezoidal - have found the greatest use. At the same time, the expediency of using trapezoid fuzzy intervals and triangular fuzzy numbers is due not only to the simplicity of performing operations on them, but also to their graphic interpretation [3].

After determining the membership functions for each llinguistic variable, the rules of fuzzy production are formed, that is, each experiment from table 2 corresponds to its own production rule. The rules written in the Matlab Rule Editor program are shown in Figure 3.

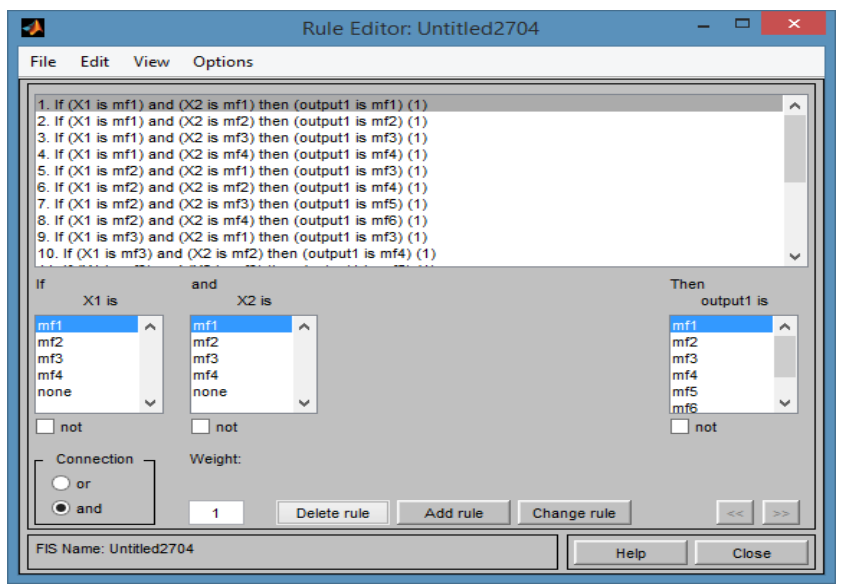

Fig. 3. Matlab Rule Editor
The rules were prescribed for the models using trapezoidal and triangular terms. As a result, two fuzzy models of optimal control of the chromium enrichment process were obtained. The interface presented in figure 4 is an optimal control model with which you can simulate various modes of operation of a jigging machine with various combinations of input variables.

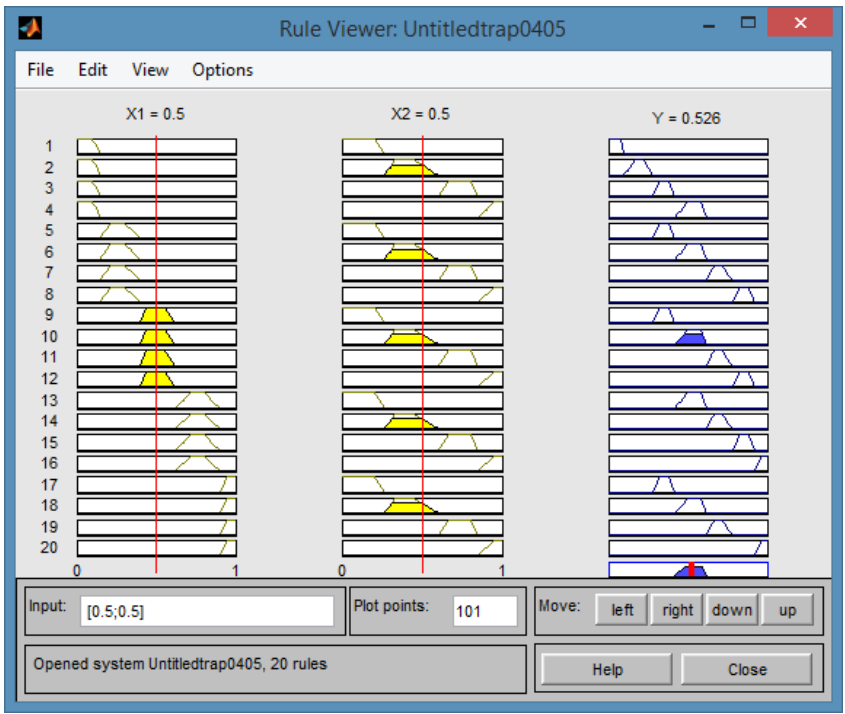

Fig. 4. Fuzzy control model with trapezoidal terms

To test the resulting models and evaluate the its adequacy a expert survey was carried out again and 20 modes of operation of the jigging machine (20 combinations of input variables) were obtained and the experts indicated the optimal output variables for these combinations. The data were tested on the obtained fuzzy models using two types of terms. The results are summarized in table 3.

Table 3. Comparative analysis of experimental and data obtained by using fuzzy models

\begin{tabular}{|c|c|c|c|c|c|c|}
\hline \multicolumn{2}{|c|}{ Factors } & \multicolumn{3}{|c|}{ Optimal value } & \multirow{2}{*}{\multicolumn{2}{|c|}{ Error, \% }} \\
\hline Concentration & $\begin{array}{l}\text { Chromium } \\
\text { concentration }\end{array}$ & \multicolumn{3}{|c|}{ Frequency of pulsation } & & \\
\hline $\mathrm{X} 1$ & $\mathrm{X} 2$ & $\mathrm{Y}^{\mathrm{E}}$ & $\mathrm{Y}^{\text {trian }}$ & $\mathrm{Y}^{\text {trapez }}$ & $\begin{array}{l}\text { trian. } \\
\text { term }\end{array}$ & $\begin{array}{l}\text { trapez } \\
\text { term. }\end{array}$ \\
\hline 0.00 & 0.00 & 0.00 & 0.03 & 0,04 & 3,00 & 4,00 \\
\hline 0.00 & 0.33 & 0.25 & 0.232 & 0,240 & 2,53 & 2,33 \\
\hline 0.00 & 0.67 & 0.4 & 0.452 & 0,463 & 1,87 & 2,97 \\
\hline 0.00 & 1.00 & 0.25 & 0.26 & 0,257 & 2,90 & 1,70 \\
\hline 0.22 & 0.00 & 0.33 & 0.363 & 0,352 & 2,97 & 1,87 \\
\hline 0.22 & 0.33 & 0.50 & 0.517 & 0,529 & 1,70 & 2,90 \\
\hline 0.22 & 0.67 & 0.67 & 0.673 & 0,698 & 0,63 & 3,13 \\
\hline 0.22 & 1.00 & 0.83 & 0.827 & 0,852 & 0,63 & 1,87 \\
\hline 0.44 & 0.00 & 0.33 & 0.363 & 0,352 & 2,97 & 1,87 \\
\hline 0.44 & 0.33 & 0.50 & 0.517 & 0,529 & 1,70 & 2,90 \\
\hline 0.44 & 0.67 & 0.67 & 0.673 & 0,698 & 0,63 & 3,13 \\
\hline 0.44 & 1.00 & 0.83 & 0.827 & 0,852 & 0,63 & 1,87 \\
\hline 0.72 & 0.00 & 0.50 & 0.517 & 0,529 & 1,70 & 2,90 \\
\hline 0.72 & 0.33 & 0.67 & 0.673 & 0,698 & 0,63 & 3,13 \\
\hline 0.72 & 0.67 & 0.83 & 0.827 & 0,852 & 0,63 & 1,87 \\
\hline 0.72 & 1.00 & 1.00 & 0.970 & 0,973 & 3,00 & 2,70 \\
\hline 1.00 & 0.00 & 1 & 0.963 & 0,952 & 2,97 & 1,87 \\
\hline 1.00 & 0.33 & 1 & 0.917 & 0,929 & 1,70 & 2,90 \\
\hline 1.00 & 0.67 & 0.85 & 0.873 & 0,898 & 0,63 & 3,13 \\
\hline 1.00 & 1.00 & 1.00 & 0.970 & 0,973 & 3,00 & 2,70 \\
\hline & & & rage enr & & 1.82 & 2.59 \\
\hline
\end{tabular}

In this table, $\mathrm{Y}^{\mathrm{E}}$ is the output value of the pulsation frequency indicated by the experts, $\mathrm{Y}^{\text {trian }}$ is the value of the pulsation frequency obtained from the fuzzy model using triangular terms, $\mathrm{Y}^{\text {trap }}$ is the value of the pulsation frequency obtained from the fuzzy model using trapezoidal terms.

As a result of analyzing the data presented in table 3 , can conclude that the absolute error in the variable "Pulsation frequency" was $1.82 \%$ for the model with triangular terms and 
$2.59 \%$ for the model with trapezoid terms. Since these values do not exceed 5\%, both models obtained using fuzzy logic are adequate. Obviously, the best is a fuzzy model with triangular terms.

The graph presented in figure 5 shows the ratio of the pulsation frequency values obtained from the models and indicated by experienced experts.

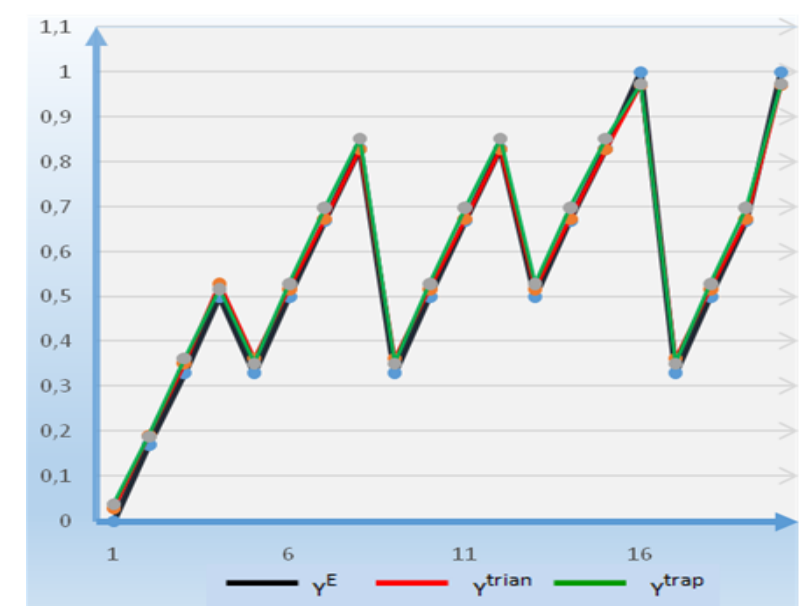

Fig. 5. The ratio of expert values, the values of the fuzzy model

\section{Conclusion}

Due to the complexity of the theoretical description and the multifactorial nature of the processes of gravitational enrichment, the application of intelligent algorithms in control them has great prospects. The use of intelligent systems to determine the key variables of the enrichment process will allow to reduce the influence of the human factor on the ore-dressing control process, which will ensure high technological performance.

Of the research made it can be concluded that the intelligence system built on the basis of fuzzy logic is able to determine the values of process variables at the level of an experienced expert technologist.

The introduction of automated controls system with intelligent subsystems of ore-dressing process, on the one hand, is associated with the costs of their acquisition. On the other hand, it allows to exclude losses of commodity concentrate and its getting into production waste. This certainly has an ecological and economic effect.

\section{References}

[1] Kozin V.Z., Tikhonov V.N.: Testing, control and automation of beneficiation processes. Nedra, Moscow 2010

[2] Morozov V.V., Topchaev V.P, Ulitenko K.Ya., Ganbaatar Z., Delgerbat L. Development and use of automated control systems for mineral processing. Ore and Metals, Moscow 2017.

[3] Nedjah N.M., Macedo L.: Fuzzy Systems Engineering. Theory and Practice. Springer Verlag, Berlin 2005.

[4] Shohin V.M.: Gravitational Enrichment Methods. Nedra, Moscow 1993.

[5] Suleimenov B.A, Sugurova L.A., Suleimenov A.B.: Intelligent systems of optimal control and operational diagnostics (methods of synthesis and application). Shikula: Almaty 2016.

[6] Swingler K.: Applying Neural Networks, a Practical Guide. Academic Press, London 1993.

[7] Tikhonov O.N.: Regularities of the effective separation of minerals in the processes of beneficiation. Nedra, Moscow 2015.

[8] Verhoturov M.: Gravitational Enrichment Methods. MAX PRESS, Moscow 2006

\section{Prof. Batyrbek Aitbaevich Suleimenov}

e-mail: batr_sul@mail.ru

$\mathrm{He}$ is head of the Department of Automotion and Control, KazNRTU after K.I. Satpayev; Doctor of Technical Sciences, Professor. Since 1975, engaged in the development and implementation of systems of optimal process control in non-ferrous metallurgy in Kazakhstan, Russia and Ukraine. Since 1990 he has been working on the problems of the use of artificial intelligence in process control. He has more than 200 publications, including 4 books in the field of research of artificial intelligence in process control.

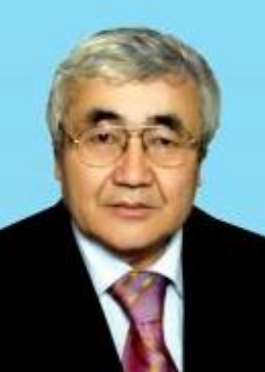

ORCID ID: 0000-0002-9177-9237

\section{M.Sc. Yelena Kulakova}

e-mail elena_winters@mail.ru

Doctoral student of the Department of Automotion and Control, KazNRTU after K.I. Satpayev; Master of technical sciences. She specializes in the field of development of automation systems, has practical experience at Donskoy Ore Mining and Processing Plant. Scientific interest: control systems of ore enrichment processes.

Publications: 6 publications - including 1 Scopus base, 1 proceedings of conference.

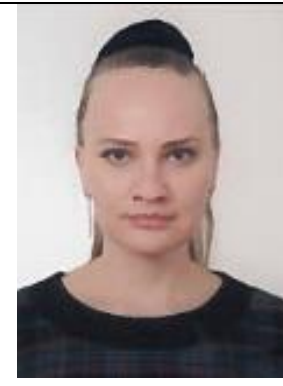

ORCID ID: 0000-0001-5307-4730

otrzymano/received: 15.05.2019 przyjęto do druku/accepted: 15.06 .2019 